ISSN: 2224-0616

Int. J. Agril. Res. Innov. Tech. 10(1): 80-86, June 2020

DOI: https://doi.org/10.3329/ijarit.v10i1.48097
OPEN 2 ACcess

Available online at https://ijarit.webs.com https://www.banglajol.info/index.php/IJARIT

\title{
Evaluation of the effect of maize-legume intercropping on soil moisture improvement in arid area of Bena-Tsemay district, South omo zone, Southern Ethiopia
}

\author{
H.M. Ayele \\ Received 15 April 2020, Revised 8 May 2020, Accepted 20 June 2020, Published online 30 June 2020
}

\section{A B S T R A C T}

\begin{abstract}
Usually crop failure due to moisture shortage in soils is very much common due to high evaporation. Sometimes famers try to combat this problem by using mulches of crop residues in the study area. However, this is also highly challenged shortage because the crop residues used as feed for animals. Therefore, using the advantage and opportunity of cover legumes as an intercrop is the solution of the problems simultaneously in addition to their contribution improving soil nutrient balance and other many fold benefits. Therefore, this study aimed for evaluating the effect of maize-legume covers intercropping on soil moisture improvement and crop yield in moisture stress areas of the study area. The entire grain yield of maize and legumes, as well as soil moisture data were collected. The result on soil moisture revealed that intercropping of maize with cowpea had better soil moisture contents during active crop development (15.98\%) and after harvest (16.70\%) in average as compared to the others. The current finding also showed that adopting intercropping of maize with cowpea-boosted yield by $5256.24 \mathrm{~kg} \mathrm{ha}^{-1}$ maize and $977.45 \mathrm{~kg} \mathrm{ha}^{-1}$ cowpea in average with higher moisture improvement as compare to the other treatments. Therefore, intercropping of maize with cowpea is important to farmers since it would provide additional crop yield with the same piece of land. However, to get considerable changes on soil and water balances, other soil physic-chemical properties and crop yields, conducting similar studies in more than two years period at permanent field plots is paramount in the future.
\end{abstract}

Keywords: Soil, Moisture, Maize, Cowpea, Lablab.

Southern Agricultural Research Institute, Jinka Agricultural Research Center, P.O.B 96, Jinka, Ethiopia.

*Corresponding author's email: mitikuayele43@gmail.com (H.M. Ayele)

Cite this article as: Ayele, H.M. 2020. Evaluation of the effect of maize-legume intercropping on soil moisture improvement in arid area of Bena-Tsemay district, South omo zone, Southern Ethiopia. Int. J. Agril. Res. Innov. Tech. 10(1): 80-86. https://doi.org/10.3329/ijarit.v10i1.48097

\section{Introduction}

Intercropping of cereals and legumes is important for the development of sustainable food production systems, particularly in cropping systems with limited external inputs and fragmented land distribution. Many studies confirmed the magnificent benefits of intercropping of cover legumes over sole cropping. High productivity and profitability, improvement of soil fertility, efficient use of resources, reducing damage caused by pests, diseases and weeds due to increased diversity (Chalk, 1998, Javanmard et al., 2009, Dahmardeh et al., 2010) are some of the benefits concluded after study. Different studies verified that cover legumes such as lablab, cowpea and vetch are highly effective in this regard (Ozpinar, 2009, Lemlem, 2013, Takim, 2012; Javanmard et al.,
2009). When combined with conservation tillage, it indicated that the contribution of these cover legumes in improving soil quality, moisture holding capacity, weed suppression and crop yield is many fold (Carrera et al., 2004).

In addition, due to their cover nature, these legumes are also highly effective in conserving soil moisture and reducing soil erosion. However, this important aspect of the legumes is usually bypassed and more focus is being given to their contribution to soil nutrients balance. When intercropped with maize verified that cover legumes such as cowpea (Bayer et al., 2000), and lablab (Janeth et al., 2014) could significantly contributed for soil moisture conservation and increased soil productivity as compared to sole maize cropping. 
In arid and moisture stress areas, usually crop failure due to moisture shortage in soils is very much common. There is high evaporation of water out of soil due to increased temperature. Sometimes farmers try to cop up with th15 problem by using mulches of crop residues in the study area of Bena-Tsemay District of South Omo Zone. However, this is also highly challenged shortage because the crop residues are used as feed for animals. Therefore, using the advantage and opportunity of cover legumes as an intercrop in moisture stress areas solve the problems simultaneously in addition to their contribution improving soil nutrient balance and other many fold benefits. However, the impact of intercropping on soil moisture improvement and soil erosion control by reducing evaporation from farm and prevent loss of soil material from farmlands has not been studied.

Therefore, this study aimed to evaluating the effect of legume covers (cowpea and lablab) intercropping with maize on soil moisture conservation and crop yield in moisture stress areas of Bena-Tsemay District of South Omo Zone.

\section{Materials and Methods}

\section{Description of the study area}

The experiments were conducted for two consecutive years (2018 and 2019) at BenaTsemay district of South Omo Zone southern Ethiopia (Fig. 1). The experimental site is geographically located with the ranges of $05^{\circ} \mathrm{O} 1^{\prime}-$ $05^{\circ} 73^{\prime} \mathrm{N}$ and $36^{\circ} 38^{\prime}-37^{\circ} 07^{\prime} \mathrm{E}$ with an elevation of $<500-2500$ m.a.s.l. It is found southern direction with $483 \mathrm{~km}$ distant from regional capital city of Hawassa. The study site has a bi-modal rainfall pattern with shorter rainy season from MarchMay and longest rainy season from AugustNovember. The total annual rainfall is $250 \mathrm{~mm}$. The annual mean minimum and maximum temperatures are $16^{\circ} \mathrm{C}$ and $40^{\circ} \mathrm{C}$, respectively (Admasu et al., 2010).

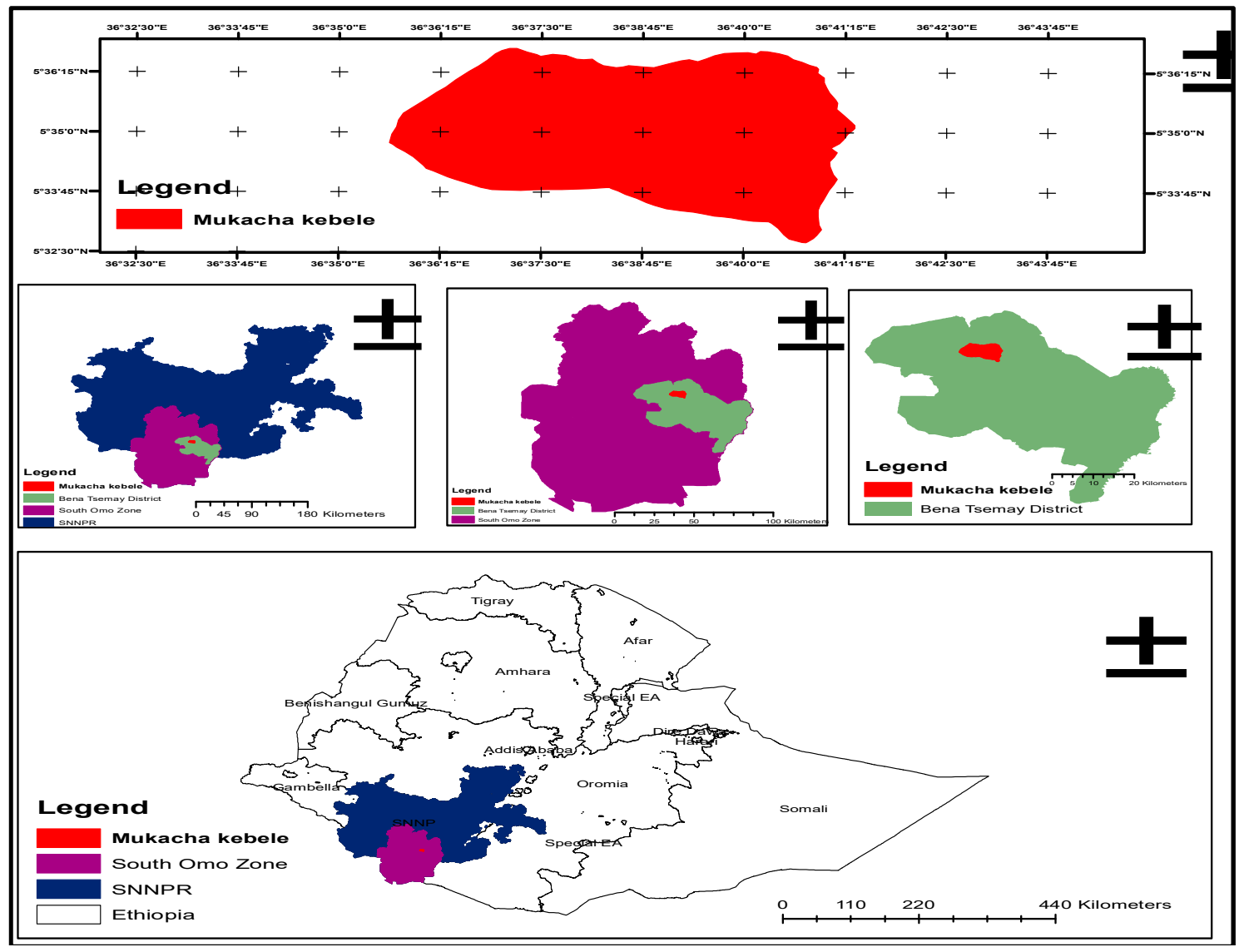

Fig. 1. The study area map.

\section{Treatments and experimental design}

The experiments were laid out in randomized complete block design (RCBD) with five treatments and with three replications on farmers' field of moisture stress area. The treatments were: Sole Maize (T1), Sole Lablab (T2), Sole Cowpea (T3), Lablab + Maize (T4) and Cowpea + Maize (T5) with $1: 1$ ratio. The experimental field was prepared by using oxen driven local plow (Maresha). The plot size of $5 \mathrm{~m}$ $\mathrm{x} 5 \mathrm{~m}$ and $1 \mathrm{~m}$ spacing between plots, also in 
intercropped treatments, maize was planted based on the recommended spacing (between rows of maize $75 \mathrm{~cm}$ and between plants $25 \mathrm{~cm}$ ) was used. However, the nitrogen fixing legume covers were planted in space between the rows of maize and in $10 \mathrm{~cm}$ spacing between plants with two seeds in a single hole, then one of which was avoided. $100 \mathrm{~kg}$ of NPSB ha-1 was applied at planting but, $75 \mathrm{~kg}$ of Urea was split twice; $50 \mathrm{~kg}$ was applied at planting for maize and legume crops as starter N. However, the remainder was applied after 35 days of planting. NPSB and Urea was used as a source of Nitrogen, Sulphur, Boron and Phosphorous. All agronomic management practices such as: weeding, pest control etc. was done in the trial period per research recommendations for maize and legumes crops.

\section{Data collection}

\section{Soil sampling}

For monitoring soil moisture status of each plot and their replication, disturbed core subsample was taken at a depth of $0-30 \mathrm{~cm}$ from each treatment at three stages: at planting, at flowering time of maize (at development stage) and after 95 days (at harvesting). However, at flowering time of maize (at development stage), core subsample was collected from the intra-row spacing of maize and each legume covers from three different points in zigzag movement. In similar manner, for those non-intercropped plots core subsample was collected from the intra-row spacing from there different points. Then, the weight of the wet soil sample was measured and then, taken to the laboratory for oven drying at $105^{\circ} \mathrm{C}$ for 24 hours. Finally, gravimetric method was used to determine the soil moisture content (available water for plant) in gram then changed in volumetric base.
In addition, at planting time composite subsurface soil sample was collected. However, at harvesting time subsurface soil samples were collected separately from each plot for the analysis of soil physic-chemical parameters (soil $\mathrm{pH}$, organic-carbon concentration (OC), total nitrogen concentration (TN), availability of Phosphorus, and exchangeable acidity was analysed.

\section{Crop data}

Grain Yield and biomass of maize and legumes were determined by harvesting the entire net plot area of $\left(16 \mathrm{~m}^{2}\right)$ out of the $25 \mathrm{~m}^{2}$ of total plot and converted into kilogram per hectare basis for grain yield and ton per hectare basis for biomass. Grain yield was adjusted to $12.5 \%$ moisture level; whereas biomass was weighed after leaving it in open air. Disease and pest event also was monitored.

\subsection{Data analysis}

The collected data were subjected to one way analysis of variance (ANOVA) using R software version $\mathrm{R} \quad \mathrm{x} 64$ 3.4.1 and Least Significant Difference (LSD) was used to separate means at $p$ $\leq 0.05$ levels of significance.

For intercropped plots, Land Equivalent Ratio (LER) will be calculated to know the total production. The LER will be estimated through the following relationship (Willey and Osiru, 1972):

Where,

$$
\text { LER }=\frac{\text { YMint }}{\text { YMsol }}+\frac{\text { YLint }}{\text { YLsol }}
$$

YMint $=$ Yield of maize under intercropping conditions. YMsol = Yield of maize under sole crop conditions.

YLint $=$ Yield of legume under intercropping conditions YLsol $=$ Yield of legume under sole crop conditions.

\section{Results and Discussion}

\section{The soil physico-chemical properties}

Table 1. The soil physico-chemical properties of sub-surface soil before the experiment.

\begin{tabular}{|lccc|}
\hline Parameters & Unit & Value & Textural class \\
\hline Clay & $\%$ & 18 & Sandy loam \\
\cline { 1 - 3 } & $\%$ & 10 & \\
\cline { 1 - 3 } Sand & $\%$ & 72 & \\
\hline pH & No & 5.50 & - \\
\hline Organic Carbon & $\%$ & 0.86 & - \\
\hline Total Nitrogen & $\%$ & 0.07 & - \\
\hline Availability of Phosphorus & $(\mathrm{ppm})$ & 11.77 & - \\
\hline Availability of Potassium & $(\mathrm{ppm})$ & 109.95 & - \\
\hline
\end{tabular}


Table 2. The soil physico-chemical properties of sub-surface soil after the experiment.

\begin{tabular}{|lccccc|}
\hline Treatments & $\mathrm{pH}($ No. $)$ & $(\% \mathrm{OC})$ & $(\% \mathrm{TN})$ & APh $(\mathrm{ppm})$ & AP $(\mathrm{ppm})$ \\
\hline Maize only & 5.99 & 1.01 & 0.08 & 7.26 & 70.95 \\
\hline Lablab only & 6.02 & 0.93 & 0.09 & 7.29 & 67.29 \\
\hline Cowpea only & 5.90 & 1.05 & 0.09 & 8.55 & 50.23 \\
\hline Lablab + Maize & 5.87 & 0.98 & 0.09 & 9.36 & 51.69 \\
\hline Cowpea + Maize & 5.96 & 1.21 & 0.12 & 7.26 & 78.51 \\
\hline
\end{tabular}

Note: NT: Total Nitrogen, OC: Organic Carbon, APh: Availability of Phosphorus and AP: Availability of Potassium.

After experiment the soil physico-chemical properties shows differences. Before and after experiment, intercropping of cowpea with maize has profound effect on soil organic carbon. The soil organic carbon on this treatment was increased from 0.86 to 1.21 . But, in all other treatments the soil organic carbon was decreased. The result agrees with the finding of Ofori et al. (2014) where soils organic carbon increased from 0.37 to 0.82 under intercropped maize with cowpea; generally contain greater organic carbon than the other type. However, the organic carbon increment was recorded, this was may be occurred due to addition of organic matter in the soil. This study indicated that the experiments were carried out on a sandy loam soil and moderately acidic area. Pre-experiment the results of soil analysis were highly very strong acidic as compare to the result after experimentation.

\section{Effect of intercropping on soil moisture contents}

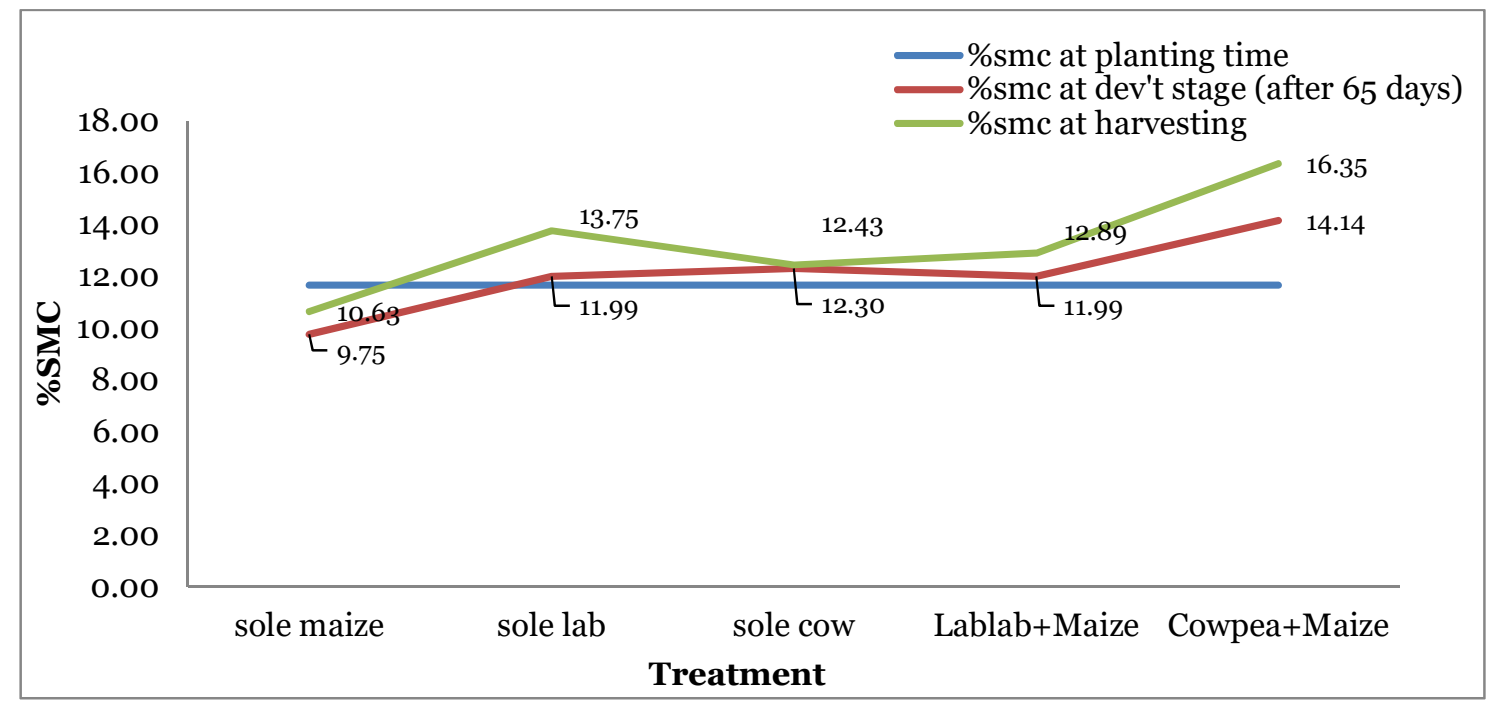

Fig. 2. Effects of intercropped maize-legume covers on \%SMC at first year.

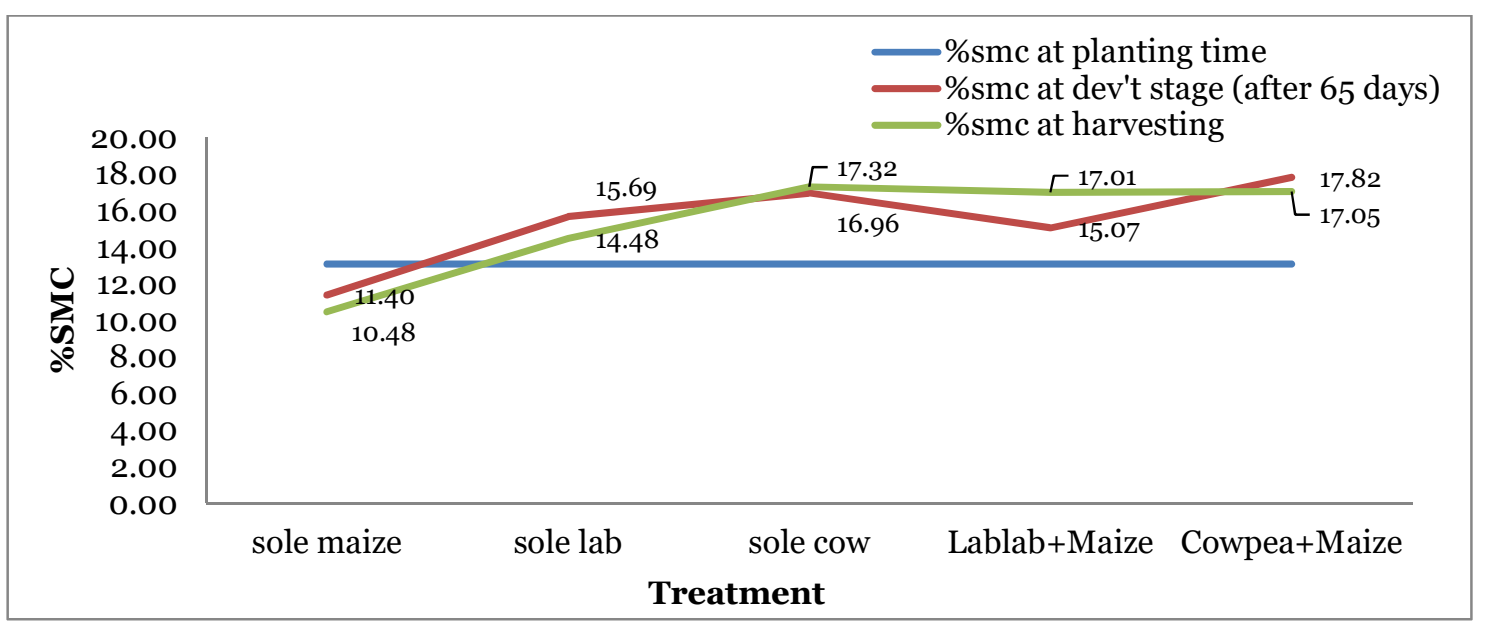

Fig. 3. Effects of intercropped maize-legume covers on \%SMC at second year. 
The study showed that there were significant effects of cropping systems on soil moisture content. Soil moisture content had significant effect at the growth stages of maize and legumes (Fig. 1 and 2). In intercropped maize with cowpea was recorded the highest moisture content. Intercropping of maize with cowpea had better soil moisture contents during active crop development (15.98\%) and after harvest (16.70\%) in average as compared to the others. However, in intercropped maize with cowpea, sole lablab and sole cowpea were recorded higher moisture content than sole maize at development stage of crops. Soil moisture content in the soil was reduced dramatically in the sole crop of maize due to high evapotranspiration potential; on the contrary soil moisture content in the soil was increased dramatically in the sole crop of cowpea due to low evapotranspiration potential for growth period. Season also had significant effect on soil moisture content. Thus, in the cowpeamaize intercrop, there might be a more fully exploitation of the soil moisture than in sole maize. Similar findings were shown by other researcher (Izaurralde et al., 1994) including greater water use efficiency in a pea-barley intercrop than in either of the sole crops. The soil collected in first year planting season had significantly lower soil moisture content than soil collected in second year planting season.

In summary, the measured soil water contents in the sole maize system were lower than those in the intercropping systems, especially when compared with the maize intercropped with cowpea.

\section{Effect of intercropping on yield and some yield components of maize and legumes}

Table $3.1^{\text {st }}$ and $2^{\text {nd }}$ year biomass and plant height result of maize crop from intercropped maize with legume crops.

\begin{tabular}{|lcccc|}
\hline \multirow{2}{*}{ Treatment } & \multicolumn{2}{c}{ Year one } & \multicolumn{2}{c|}{ Year two } \\
& Biomass $\left(\mathrm{t} \mathrm{ha}^{-1}\right)$ & Plant height $(\mathrm{cm})$ & Biomass $\left(\mathrm{t} \mathrm{ha}^{-1}\right)$ & Plant height $(\mathrm{cm})$ \\
\hline Maize only & $45.20 \mathrm{ab}$ & 172.13 & 58.20 & 169.32 \\
\hline Lablab + Maize & $51.70 \mathrm{a}$ & 167.40 & 58.30 & 177.30 \\
\hline Cowpea + Maize & $39.60 \mathrm{~b}$ & 171.20 & 46.25 & 174.50 \\
\hline CV $(\%)$ & 20.90 & 1.62 & 7.04 & 1.71 \\
\hline Mean & 42.20 & 170.24 & 54.26 & 173.71 \\
\hline LSD (5\%) & 10.00 & NS & NS & NS \\
\hline
\end{tabular}

Note: Mean values with different letters within the column are statistically different at $P \leq 0.05$.

The on-farm experiments did not present significant differences in maize plant height between cropping system in both years at $\mathrm{P} \leq 0.05$ (Table 3). Similarly, in terms of biomass there was no significant difference in the second year at $\mathrm{P} \leq$ 0.05. However, there was significant difference among cropping systems in first year at $\mathrm{P} \leq 0.05$. The highest biomass was observed from the maize intercropped with lablab, when the lowest was observed from the maize intercropped with cowpea. The results showed that no significant difference in yield parameters (plant height and biomass) of maize among cropping systems. This result is similar to the study of (Thwala and Ossom, 2004; Arun, 2016) in which no significant difference was found in yield components (plant height, active leaf number per plant and grain number per cob) when maize was intercropped with groundnut and sugar bean. Mburu et al. (2011) reported that in intercrops usually the maize has a competitive advantage over legumes for light and water since they are tall and with larger root system and hence experience limited competition.

Table $4.1^{\text {st }}$ and $2^{\text {nd }}$ year biomass and plant height result of legume crop from intercropped maize legume covers crops.

\begin{tabular}{|lcccc|}
\hline Treatment & $\begin{array}{c}\text { Year one } \\
\text { Biomass }\left(\mathrm{t} \mathrm{ha}^{-1}\right)\end{array}$ & Plant height $(\mathrm{cm})$ & $\begin{array}{c}\text { Year two } \\
\text { Biomass }\left(\mathrm{t} \mathrm{ha}^{-1}\right)\end{array}$ & Plant height $(\mathrm{cm})$ \\
\hline Lablab only & $17.92 \mathrm{ab}$ & 56.33 & $39.56 \mathrm{a}$ & 58.42 \\
\hline Cowpea only & $14.68 \mathrm{~b}$ & 55.80 & $24.69 \mathrm{~b}$ & 56.70 \\
\hline Lablab + Maize & $26.04 \mathrm{a}$ & 54.07 & $36.04 \mathrm{a}$ & 53.02 \\
\hline Cowpea + Maize & $25.00 \mathrm{a}$ & 55.00 & $21.85 \mathrm{~b}$ & 58.90 \\
\hline CV $(\%)$ & $24.6 \mathrm{O}$ & $6.6 \mathrm{o}$ & 10.64 & 6.20 \\
\hline Mean & 18.41 & 55.30 & 30.53 & 56.76 \\
\hline LSD $(5 \%)$ & 6.49 & $\mathrm{Ns}$ & 9.05 & Ns \\
\hline
\end{tabular}

Note: Mean values with different letters within the column are statistically different at $P \leq 0.05$. 
The study result revealed that the biomass of intercropped with lablab (26.04 $\left.\mathrm{t} \mathrm{ha}^{-1}\right)$ and the legume crops was significantly different at lowest was recorded from the cowpea only sown $\mathrm{P} \leq 0.05$. The highest was recorded from the maize treatment.

\section{Effect of intercropping on land use efficiency}

Table 5. Land Equivalent Ratio of intercropping of maize with legume crops at first year.

\begin{tabular}{|lccc|c|}
\hline Treatment & $\begin{array}{c}\text { GY of Lablab } \\
\left(\mathrm{kg} \mathrm{ha}^{-1}\right)\end{array}$ & $\begin{array}{c}\text { GY of cowpea } \\
\left(\mathrm{kg} \mathrm{ha}^{-1}\right)\end{array}$ & $\begin{array}{c}\text { GY of maize } \\
\left(\mathrm{kg} \mathrm{ha}^{-1}\right)\end{array}$ & LER \\
\hline Maize only & $\ldots \ldots \ldots$ & $\ldots \ldots \ldots \ldots$. & 5259.58 & \\
\hline Lablab only & 1150 & & $\ldots \ldots .$. & \\
\hline Cowpea only & $\ldots \ldots$. & 1110 & $\ldots \ldots$. & 1.7 \\
\hline Lablab + Maize & 869 & $\ldots \ldots \ldots \ldots .$. & 5038.53 & 1.9 \\
\hline Cowpea + Maize & $\ldots \ldots \ldots$ & 977.45 & 5256.24 & \\
\hline
\end{tabular}

Note: LER stands for land equivalent ratio.

The effect of intercropping maize-legume covers on maize yield and yield components was evaluated for two years period. Land equivalent ratio was used to evaluate the land use efficiency and that means evaluating of intercropping efficiency in yield relative to the mono-cropped condition. The calculated LER for the grain yield of maize and lablab was 1.7, while 1.9 LER was obtained from the intercropping of maize with cowpea. Therefore, intercropping showed an advantage over sole cropping in the trial seasons. The higher yield under mono-cropped condition is directly related with lack of competition for nutrient and moisture. However, the analysis result in the (Table 5) above, indicated that the equivalent ratio (LER) of maize intercropped with lablab and cowpea was greater than 1 which indicated the benefits of intercropping. This result is similar to the study of (Gebremichael et al., 2019) who reported that intercropping sorghum cowpea increases the land productivity (LER $>1$ ) indicating the benefits of intercropping.

\section{Conclusion and Recommendation}

Usually crop failure due to moisture shortage in soils is very much common due to high evaporation. Sometimes famers try to combat this problem by using mulches of crop residues in the study area. But this is also highly challenged shortage because the crop residues are used as feed for animals. Therefore, using the advantage and opportunity of cover legumes as an intercrop is the solution of the problems simultaneously in addition to their contribution improving soil nutrient balance and other many fold benefits.

The current study result indicated that in terms of biomass of maize and legume intercropping of maize with lablab gave the highest biomass. However, in terms of LER of yield and soil moisture improvement intercropping of maize with cowpea was the best advantageous. Also in terms of farmers preference intercropping of maize with cowpea was chosen by farmers. Obtaining additional food grain is an attractive option for the farmers having land shortage to plant maize and cow pea separately. The benefit of obtaining additional legume grain would have positive advantage on food security and land use efficiency. Hence, for better productivity of the intercropping system, further study should be done by considering other factors of production.

\section{Acknowledgements}

First of all, I would like to extend my great appreciation to Southern Agricultural Research Institute and Jinka Agricultural Research Center for the funding. Next to this I would like to thank all researchers of natural resource research directorate for their constructive advices and coherences.

\section{References}

Admasu, T., Abule, E. and Tessema, Z.K. 2010. Livestock-rangeland management practices and community perceptions towards rangeland degradation in the South Omo zone of Southern Ethiopia. Livestock Res. Rural Dev. 22(1): 1-17.

Arun, T. 2016. On-farm evaluation of maize and legume intercropping for improved crop productivity in the mid hills of Nepal. LAP LAMBERT Academic Publishing, Germany. $92 \mathrm{p}$.

Bayer, C., Mielniczuk, J., Amado, T.J., MartinNeto, L. and Fernandes, S.V. 200o. Organic matter storage in a sandy clay loam Acrisol affected by tillage and cropping systems in southern Brazil. Soil Tillage Res. 54(1-2): 101-109. https://doi.org/10.1016/So1671987(00)00090-8

Carrera, L.M., Abdul-Baki, A.A. and Teasdale, J.R. 2004. Cover crop management and weed suppression in no-tillage sweet corn production. HortSci. 39(6): 1262-1266.

Chalk, P.M. 1998. Dynamics of biologically fixed $\mathrm{N}$ in legume-cereal rotations: a review. Australian J. Agril. Res. 49(3): 303-316. https://doi.org/10.1071/A97013 
Dahmardeh, M., Ghanbari, A., Syahsar, B.A. and Ramrodi, M. 2010. The role of intercropping maize (Zea mays L.) and cowpea (Vigna unguiculata L.) on yield and soil chemical properties. African J. Agril. Res. 5(8): 631636.

Gebremichael, A., Bekele, B. and Tadesse, B. 2019. Evaluation of the effect of sorghumlegume intercropping and its residual effect on yield of sorghum in yeki woreda, sheka zone, Ethiopia. Int. J. Agril. Res. Innov. Tech. 9(2): 62-66. https://doi.org/10.3329/ijarit.v9i2.45412

Izaurralde, R.C., Chanasyk, D.S. and Juma, N.G. 1994. Soil water under conventional and alternative cropping systems in cryoboreal sub-humid central Alberta. Canadian J. Soil Sci. 74(1): 85-92. https://doi.org/10.4141/cjss94-011

Janeth, C., Onwonga, R.N., Karuku, G.N. and Kathumo, V.M. 2014. Efficiency of Combined Tillage Practices, Cropping Systems and Organic Inputs on Soil Moisture Retention in Yatta Sub-County, Kenya. $J$. Agric. Environ. Sci. 3(2): 145-156.

Javanmard, A., Nasab, A.D.M., Javanshir, A., Moghaddam, M. and Janmohammadi, $H$. 2009. Forage yield and quality in intercropping of maize with different legumes as double-cropped. J. Food Agric. Environ. 7(1): 163-166.

Lemlem, A. 2013. The effect of intercropping maize with cowpea and lablab on crop yield. Herald J. Agric. Food Sci. Res. 2(5): 156-170.
Mburu, M.W.K, Mureithi, J.G. and Gachene, C.K.K. 2011. Water and light use in maize intercropped with Mucuna. Oral presentation at aGRO 2011 Biennial Conference, Faculty of Agriculture, University of Nairobi. pp. 156-177.

Ofori, E., Oteng-Darko, P., Berchie, J.N., Nimako, F.O., Yeboah, S. and Danquah, E.O. 2014. Monitoring of soil moisture regime and water use efficiency under maize cowpea cropping system. Int. J. Curr. Microbiol. App.Sci. 3(10): 837-848.

Ozpinar, S. 2009. Tillage and cover crop effects on maize yield and soil nitrogen. Bulgarian J. Agril. Sci. 15(6): 533-543.

Takim, F.O. 2012. Advantages of maize-cowpea intercropping over sole cropping through competition indices. J. Agric. Biodiv. Res. 1(4): 53-59.

Thwala, M.G. and Ossom, E.M. 2004. Legumemaize association influences crop characteristics and yields. In: Proc. of the $4^{\text {th }}$ International Crop Science Congress. Faculty of Agriculture, University of Swaziland.

Willey, R.W. and Osiru, D.S.O. 1972. Studies on mixtures of maize and beans (Phaseolus vulgaris) with particular reference to plant population. J. Agric. Sci. Cambridge. 79: 519-529.

https://doi.org/10.1017/So021859600025909 